David Amar MD, L. Elizabeth Brodman MD, Steven A. Winikoff MD, lngrid Hollinger MD

\title{
An alternative oxygen delivery system for infants and children in the post-anaesthesia care unit
}

This randomized controlled trial compared the compliance of a blow-by oxygen method with the standard face mask by children recovering from anaesthesia. The rate at which a face mask was rejected when applied to infants and children in PACU was compared with that of a proposed "hose" method. The efficacy of the "hose" as a method of oxygen supplementation in children at low and high risk for developing postoperative hypoxaemia was also compared with the face mask. Using a Nellcor N-200 pulse oximeter, 66 infants and children (mean age $2.3 \mathrm{yr}$, range 2 mo-6 yr) were continuously monitored for 30 min upon arrival in the PACU. Patients were randomized to receive oxygen supplementation with either the face mask or the proposed "hose" method. The results showed a greater than 80 per cent rejection of the face mask in contrast to 100 per cent compliance with the "hose" method. The $\mathrm{SaO}_{2}$ measurements following 5 , 15 and 30 min of $\mathrm{O}_{2}$ supplementation with the hose were all significantly higher than the $\mathrm{SaO}_{2}$ measurements obtained on room air upon arrival to the PACU. Patients with pre-existing cardiopulmonary disease had a 20 per cent incidence of arterial oxygen desaturation upon arrival to the PACU versus 2.1 per cent of patients with no pre-existing disease. It is concluded that the "hose" is associated with high parient compliance and is effective in the PACU in increasing the $\mathrm{SaO}_{2}$ in children at low or high risk of developing postoperative hypoxaemia

\section{Key words}

ANAESTHESIA: paediatric;

HYPOXIA: perioperative;

OXYGEN: delivery systems, monitoring, oximetry.

From the Department of Anesthesiology, Montefiore Medical Center and Albert Einstein College of Medicine, 111 East 210th Street, Bronx, NY 10467.

Presented in part at the 63rd Congress of the International Anesthesia Research Society, Orlando, FL, March 5, 1989.

Address correspondence 10: Dr. D. Amar, Department of Anesthesiology and Critical Care Medicine, Memorial Sloan-Kettering Cancer Center, 1275 York Avenue, New York, NY 10021.

Accepted for publication 2/st August, 1990.
Cette étude randomisée et contrôlée compare la compliance de la méthode d' " insuflation " de l'oxygène avec celle du masque facial standard pour les enfants en période de réveil de l'anesthésie. Le taux de rejet du masque, quand appliqué cuar bébés et enfants à l'unité de soins postanesthésiques, a été comparé avec celui proposé et appelé la méthode par "insuflation ». L'efficacité de cette dernière méthode pour l'oxygénation des enfants à risque faible ou élevé de développer de l'hypoxémie postopératoire a aussi été comparée avec la méthode du masque facial. Utilisant le Nellcor $N$-200 saturomètre de pouls 66 bébés et enfants (moyenne d'âge 2,3 ans, écart 2 mois-6 ans) ont été surveillés continuellement pour 30 minutes dès l'arrivée à l'unité des soins postanesthésiques. Les patients furent randomisés afin de recevoir de l'oxygène par l'une ou l'autre des méthodes. Les résultats ont démontré un plus grand taux de rejet du masque facial (80 pour cent) et une compliance de 100 pour cent à la méthode d" "insuflation ». Les mesures de la $\mathrm{SaO}_{2}$ après 5,15 et 30 minutes de supplément d'oxygène par "insuflation" étaient aussi significativement supérieures aux saturations à mesurer à l'arrivée à l'unité des soins postanesthésiques avec l'air libre. Les patients ayant des maladies cardiopulmonaires pré-existantes avaient une incidence de 20 pour cent de désaturation artérielle dès leur arrivée à l' unité des soins postanesthésiques versus 2,I pour cent chez les patients qui étaient exempts de maladie pré-existante. On conclut que la méthode d' insuflation" est associée avec une plus grande acceptation par le patient et a été efficace afin d'augmenter la saturation $\mathrm{SaO}_{2}$ à l'unité des soins postanesthésiques chez les enfants ayant un risque faible ou élevé de développer de l'hypoxémie postopératoire.

Hypoxaemia following general anaesthesia in infants and children has been well documented. ${ }^{1,2}$ The face mask is a widely used method of administering oxygen in the post-anaesthesia care unit (PACU). However, application of a face mask for oxygen therapy frequently provokes unnecessary agitation and anxiety. There may also be a risk of damage to the eyes from the mask or strap during this excitable period. The "hose" method is a blow-by oxygen technique. There are no reports in the literature 


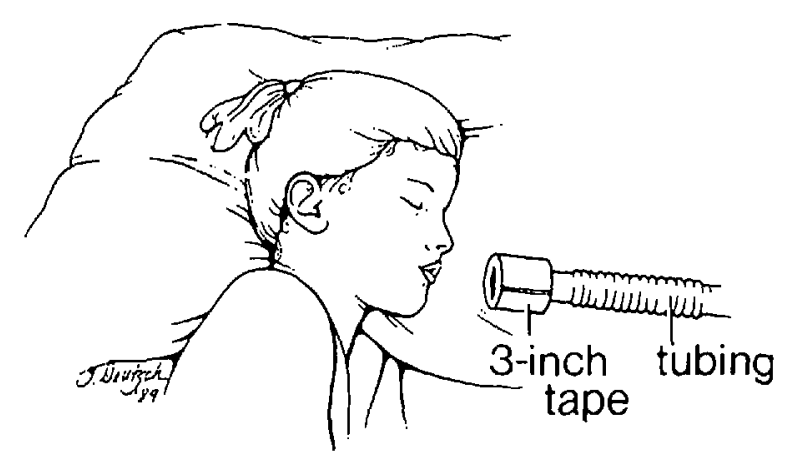

FIGURE Proposed "hose" method of oxygen administration.

documenting continuous pulse oximetry with the use of any blow-by method. Current practice is to administer $\mathrm{O}_{2}$ to all paediatric patients recovering from anaesthesia.

The objectives of this study were: to determine the incidence at which the "standard" face mask was rejected in the PACU in comparison with the "hose," and to determine whether the proposed "hose" method was effective in increasing the $\mathrm{SaO}_{2}$ from baseline on room air, in infants and children recovering from anaesthesia.

\section{Methods}

The study was approved by the institutional review board and parental consent was obtained. Seventy-two ASA physical status I-III patients between two months and six years of age, scheduled for surgery under general anaesthesia, were entered into the study. Patients were excluded from the study if they had a tracheostomy or if tracheal intubation was continued postoperatively. Premature infants weighing less than $3.5 \mathrm{~kg}$ requiring a head box for postoperative oxygenation and patients requiring nebulized medications in the PACU were also excluded from this study. The patients were then randomly allocated to receive oxygen supplementation in the PACU by either a face mask $(n=36)$ or by the "hose" method $(n=36)$, (Figure). Patients were further identified within their allocated group of $\mathrm{O}_{2}$ supplementation to be at low and high risk of developing postoperative hypoxaemia. The high risk criteria were: patients with a history of coexisting lower and/or upper respiratory tract disorders, a history of prematurity (up to $50 \mathrm{wk}$ postconceptual age), anaemia (haematocrit $\leq 28$ per cent), sickle cell disease, obesity, and cardiac disease (Table I). The choice of premedication or anaesthetic technique was not restricted. The decision to administer muscle relaxants and/or opioid analgesics was made by the staff anaesthetist caring for the patient. Arterial oxygen saturation $\left(\mathrm{SaO}_{2}\right)$ measurements were obtained in the operating room using the Nellcor N-100 and in the PACU using the Nellcor N-200 with ECG-synchronization. With the exception of two patients in whom anaesthesia was induced with thiopentone, the patients had a mask induction of anaesthesia with nitrous oxide and halothane. The initial study measurements were made as soon as the child ceased moving after induction of anaesthesia. Upon completion of surgery the patients received 100 per cent $\mathrm{O}_{2}$ by mask for 3-5 $\mathrm{min}$ and then were allowed to breathe room air for three minutes before and during transfer to the PACU. Pulse oximetry measurements were obtained in the following sequence: during induction $\mathrm{FIO}_{2} 0.3$, at the end of surgery after breathing room air for three minutes, upon arrival in the PACU after breathing room air for three minutes, and at 5,15 and 30 min following $\mathrm{O}_{2}$ supplementation in the PACU. Although recordings of $\mathrm{SaO}_{2}$ were made at six time points, the patients were continuously monitored for $30 \mathrm{~min}$. Blood pressure and heart rate were also recorded at the same intervals. In the PACU, following baseline measurements, humidified oxygen supplementation consisted of $6-8 \mathrm{~L} \cdot \mathrm{min}^{-1}$ to patients $<2$ yr and at $8-10 \mathrm{~L} \cdot \mathrm{min}^{-1}$ to patients $2-6 \mathrm{yr}$ of age, with either method of delivery. Lower fresh gas flows were delivered to children $<2$ yr to minimize cooling and the diving reflex. Rejection of the $\mathrm{O}_{2}$ delivery source was defined as the sudden appearance of agitation, grimacing and crying provoked by applying the $\mathrm{O}_{2}$ supplementation in infants from two to six months old or the physical removal of the $\mathrm{O}_{2}$ supplementation source by children from six months to six years of age. If the face mask was rejected, following two attempts by the nurse, the patient was switched to the "hose" method and the study measurements were obtained as per protocol. No patient was allowed to breathe room air following rejection of the $\mathrm{O}_{2}$ supplementation source. The presence or absence of crying, restlessness, nausea, vomiting, airway obstruction and the need for sedation were also recorded by the nurse.

\section{Statistical analysis}

The difference between the proportions of patients who

TABLE I Coexisting discase in the high-risk group

\begin{tabular}{ll}
\hline Number of parients & Coexisting disease* \\
\hline 6 & Airway obstruction \\
5 & Asthma \\
5 & Upper rcspiratory tract infection \\
3 & Ex-prematurc \\
3 & Apnoca \\
2 & Sickle cell discasc \\
1 & Pncumonia \\
1 & Cardiomyopathy \\
1 & Tracheomalacia \\
\hline
\end{tabular}

*Some patients had more than one disease. 
TABLE Il $\mathrm{SaO}_{2}$ measurements in the PACU

\begin{tabular}{|c|c|c|c|c|c|c|c|c|c|c|}
\hline & \multirow[b]{2}{*}{ Group } & \multirow[b]{2}{*}{$n$} & \multicolumn{2}{|l|}{$T_{1}$} & \multicolumn{2}{|l|}{$T_{2}$} & \multicolumn{2}{|l|}{$T_{3}$} & \multicolumn{2}{|l|}{$T_{4}$} \\
\hline & & & Mean $\pm S D$ & Range & $M e a n \pm S D$ & Range & Mean $\pm S D$ & Range & $M e a n \pm S D$ & Range \\
\hline \multirow[t]{2}{*}{ I } & Low risk & 25 & $97.4 \pm 2$ & $91-100$ & $99.5 \pm 0.8 *$ & $97-100$ & $99.3 \pm 0.9^{*}$ & $97-100$ & $99.3 \pm 1.0^{*}$ & $96-100$ \\
\hline & High risk & 9 & $94.1 \pm 4.3$ & $88-100$ & $99.6 \pm 0.5^{*}$ & $99-100$ & $99.6 \pm 0.7^{*}$ & $98-100$ & $99.3 \pm 0.9^{*}$ & $98-100$ \\
\hline \multirow[t]{2}{*}{ II } & Low risk & 17 & $97.5 \pm 2.5$ & $91-100$ & $99.5 \pm 1.1^{*}$ & $96-100$ & $99.6 \pm 0.7^{*}$ & $98-100$ & $99.5 \pm 0.8^{*}$ & $98-100$ \\
\hline & High risk & 9 & $92.7 \pm 10.1$ & $68-100$ & $99.0 \pm 1.3^{*}$ & $96-100$ & $98.2 \pm 2.5^{*}$ & $92-100$ & $99.2 \pm 0.8^{*}$ & $98-100$ \\
\hline \multirow[t]{2}{*}{ III } & Low risk & 4 & $94.5 \pm 5$ & $88-100$ & $99.8 \pm 0.5^{*}$ & $99-100$ & $100 \pm 0.0^{*}$ & 100 & $99.3 \pm 1.0^{*}$ & $98-100$ \\
\hline & High risk & 2 & $95.5 \pm 0.7$ & $95-96$ & $100 \pm 0^{*}$ & 100 & $99.5 \pm 0.7^{*}$ & $99-100$ & $99.5 \pm 0.7^{*}$ & $99-100$ \\
\hline
\end{tabular}

* $P<0.05, \mathrm{SaO}_{2}$ significantly higher than baseline for cach subgroup, respectively.

$\mathrm{T}_{1}$ - Room air, bascline $\mathrm{SaO}_{2}$ in PACU.

$\mathrm{T}_{2}-5$ min following $\mathrm{O}_{2}$ supplementation.

$\mathrm{T}_{3}-15$ min following $\mathrm{O}_{2}$ supplementation.

$\mathrm{T}_{4}-30 \mathrm{~min}$ following $\mathrm{O}_{2}$ supplementation.

rejected the assigned $\mathrm{O}_{2}$ supplement method were tested using Fisher's exact test; changes in $\mathrm{O}_{2}$ saturation and heart rate were tested using a paired and unpaired t test. All tests performed were two-tailed with $P<0.05$ considered statistically significant. The Bonferroni multiple comparison procedure was used to adjust the type-I error, because two tests were performed for the two strata. The Kruskal Wallis test was used to compare $\mathrm{SaO}_{2}$ measurements in the PACU among the patients who were allocated to the "hose" treatment, those rejecting the mask but used the "hose" and those allocated to receive the mask also used the mask.

\section{Results}

Sixty-six patients completed the study, 34 were allocated to the "hose" treatment and 32 to the mask treatment. Of the six patients who were excluded, two required nebulized aerosol therapy for asthma, three were extremely active and baseline data could not be obtained in the PACU, and in one patient the trachea remained intubated upon arrival to the PACU. The mean age for the entire study population was $2.3 \pm 1.5 \mathrm{yr}$.

\section{Rejection of oxygen supplementation}

The incidence of rejection of the mask within the first five minutes in PACU was 81.0 per cent (17/21) in the low-risk group and 81.8 per cent $(9 / 11)$ in the high-risk group. No patient rejected the hose in either group. There was no association among all four groups between rejection of the mask and crying, restlessness and need for sedation throughout the stay in the PACU.

\section{$\mathrm{SaO}_{2}$ measurements}

The induction $\mathrm{SaO}_{2}\left(\mathrm{FiO}_{2}\right.$ 0.3) measurements were not statistically different from the $\mathrm{SaO}_{2}$ measurements on room air at the end of surgery (prior to transfer) among all groups.

Three subsequent groups were identified for analysis. Group I included patients allocated to the "hose" treatment and used the "hose." Group II included patients that were allocated to the mask treatment but were switched to the "hose" following rejection of the mask. Group III patients were allocated to the mask treatment and used the mask. The improvements in $\mathrm{SaO}_{2}$ measurements from room air following administration of $\mathrm{O}_{2}$ with the hose were statistically significant $(P<0.05)$ for both the low- and high-risk groups as shown in Table II. The mask sample size was small due to the high rate of rejection of the mask in the PACU. There were no significant differences among the groups in $\mathrm{SaO}_{2}$ at each of the time points (Kruskal Wallis test).

\section{Hypoxaemia in the PACU}

The incidence of oxygen desaturation $\left(\mathrm{SaO}_{2}<90\right.$ per cent) on arrival at the PACU was $1 / 46$ (2.1 per cent) in the low-risk group and significantly higher 4/20 (20 per cent) $(P<0.05)$ in the high-risk group. The patients that developed an $\mathrm{SaO}_{2}<90$ are described in Table IlI. Apnoea or airway obstruction was not observed in the patient with an $\mathrm{SaO}_{2}$ of 68 per cent. There was no associa-

TABLE III Patients with $\mathrm{SaO}_{2}<90$ per cent in the PACU

\begin{tabular}{llcll}
\hline $\begin{array}{l}\text { Risk } \\
\text { group }\end{array}$ & Coexisting disease & Age & Type of surgery & $\begin{array}{l}\mathrm{SaO}_{2} \\
(\%)\end{array}$ \\
\hline Low & Nonc & $4 \mathrm{yr}$ & Myringotomy & 88 \\
High & Sickle cell diseasc, URI & $2 \mathrm{mo}$ & Hernia repair & 68 \\
High & Chronic secretions & $14 \mathrm{mo}$ & Hemia rcpair & 86 \\
High & Tracheomalacia & $8 \mathrm{mo}$ & Ptosis repair & 88 \\
High & Pneumonia & $1 \mathrm{yr}$ & PDA ligation & 88 \\
\hline
\end{tabular}


tion between hypoxaemia $\left(\mathrm{SaO}_{2}<90\right.$ per cent) and the use of barbiturates and/or opioids perioperatively.

\section{Discussion}

The occurrence of hypoxaemia and the benefit of administering oxygen in the immediate postoperative period have been documented in adults, ${ }^{1-8}$ as well as in infants and children..$^{9-14}$ The cause for this early deterioration in arterial oxygenation is probably multifactorial. Alveolar hypoventilation, $\dot{V} / \dot{Q}$ mismatch, right-to-left shunting of blood, depressed cardiac output and increased oxygen consumption due to hypertonic muscles and shivering are potential causative factors. ${ }^{2}$

There are several methods for administering oxygen to patients in the PACU. One objective of this study was to compare the rates of rejection of the face mask and the "hose." The face mask was used as the common method of oxygen supplementation in the PACU. Some children were crying upon arrival to the PACU, and that was noted by the PACU nurse. However, it was the additional agitation or physical removal that was caused by applying a face mask that we considered important. In this study, we found that patient compliance was 100 per cent when the "hose" was used compared with less than 20 per cent with the standard face mask. This does not imply that patients receiving the "hose" did not become agitated or grimace during their stay in the PACU. The second objective of this study was to determine the efficacy of the "hose" in increasing the baseline $\mathrm{SaO}_{2}$ measurements in the PACU on room air. We showed significant improvements in $\mathrm{SaO}_{2}$ from room air upon arrival to the PACU with the "hose" in both the low- and high-risk patients. Due to the high rejection of the mask, patients were switched to receive the "hose" (Group II) and their $\mathrm{SaO}_{2}$ measurements were subsequently made on the "hose." An important limitation of this study was the lack of a "control" group - patients who received no oxygen in the PACU. This was a difficult ethical issue since $\mathrm{O}_{2}$ is routinely given to all paediatric patients in carly recovery. Thus, these patients were not allowed to breathe room air for the remaining time in the PACU.

There are no other reports in paediatric patients describing the efficacy of a blow-by oxygen technique which the "hose" method represents. This method offers the benefit of oxygenation without physical contact with the child, which may be frightening and damage the eyes or face from the strap. The "hose" can be redirected by the nurse if the child moves his head. Although this may occur frequently in this population we have found that the compliance with this method is superior to the mask and our continuous oximetry monitoring did not reflect fluctuations in $\mathrm{SaO}_{2}$ once supplementation had begun.
One consequence of blowing oxygen over the newborn's face is apnoea and bradycardia (the diving reflex). This was not seen in this study or in our practice with these fresh gas flows.

In patients at low risk of developing postoperative hypoxaemia we found that one of 46 patients $(2.2$ per cent) had an $\mathrm{SaO}_{2}<90$ per cent, while four of 20 patients (20 per cent) at high risk developed an $\mathrm{SaO}_{2}<90$ per cent. Others ${ }^{10,12}$ have described an incidence of $0-43$ per cent of $\mathrm{SaO}_{2}<91$ per cent in low-risk patients, and a 20 per cent incidence in high-risk patients, ${ }^{12}$ upon arrival to the PACU. The use of opioids did not increase the risk of desaturation in our experience as well as that of others. ${ }^{10}$ Children may desaturate during transport before arrival in the PACU ${ }^{13.14}$ Most would agree that oxygen should be given in the PACU to infants and children in the immediate postanaesthetic period to overcome the relative hypoxia due to anaesthesia. Whether supplemental oxygen is indicated in all infants and children during transportation is controversial. Patel et al. ${ }^{14}$ showed that $\mathrm{O}_{2}$ supplementation during transport prevented hypoxaemia in most low-risk patients. However, in the case of a tragic event (e.g., laryngospasm etc.) a closed system with a reservoir would be necessary to prevent an adverse outcome. Of concern to us was the more severe and sustained desaturation observed in some high-risk patients in the PACU, and not seen in the low-risk group. Based on our results in the PACU and that of others ${ }^{12,14}$ we agree with the use of oxygen supplementation during transportation in low- and high-risk patients and perhaps this would prevent severe desaturation on arrival to the PACU. We speculate that the "hose" method is suitable as a supplementation method in most patients, during transportation to the PACU, and is a simple and inexpensive apparatus.

In summary, this study showed that the conventional face mask is rejected by $>80$ per cent of infants and children in the immediate postoperative period. We recommend the use of the "hose" as an alternative method of oxygen administration because it is associated with greater patient compliance, as well as being effective in improving $\mathrm{SaO}_{2}$ from a room air baseline both in patients at low or high risk of developing postoperative hypoxaemia. We have also confirmed that patients with coexisting disease (cardiopulmonary/airway disorders, anaemia and ex-prematurity) are at higher risk of developing severe hypoxaemia in the immediate post-anaesthetic period.

\section{Acknowledgements}

The authors thank Fran Reiner RN, Angela Maddalone RN, and Mildred Pleasant for their assistance; Katherine Freeman DPH for her help with the statistical design and 
analysis; Nellcor Inc. for providing technical assistance and Dr. Peter T. Rothstein for his critical review of this manuscript.

\section{References}

1 Nunn $J F$, Payne $P$. Hypoxaemia after general anaesthesia. Lancet 1962; $2: 631-2$

2 Marshall $B E$, Wyche $M Q J r$. Hypoxemia during and after anesthesia. Anesthesiology 1972; 37: 178-209.

3 Selim D, Markello R, Baker JM. The relationship of ventilation to diffusion hypoxia. Anesth Analg 1970; 49 : 437-40.

4 Sheffer L, Steffenson JL, Birch AA. Nitrous oxide diffusion hypoxia in patients breathing spontaneously. Anesthesiology 1972; 37: 436-9.

5 Tyler $I L$, Tantisira B, Winter PM, Motoyama EK. Continuous monitoring of arterial oxygen saturation with pulse oximetry during transfer to the recovery room. Anesth Analg 1985; 64: 1108-12.

6 Meiklejohn BH, Smith $G$, Elling AE, Hindocha N. Arterial oxygen desaturation during postoperative transportation: the influence of operation site. Anaesthesia 1987; 42 : 1313-5.

7 Vegfors $M$, Cedarholm I, Lennmarken C, Liofsrriom IB. Should oxygen be administered after laparoscopy in healthy patients? Acta Anaesthesiol Scand 1988; 32: 350-2.

8 Smith $D C$, Crul JF. Early postoperative hypoxia during transport. Br J Anaesth 1988; 61: 625-7.

9 Brown $M D$, Kallar $S$. Hypoxemia in children following gencral anesthesia in the ambulatory surgery center. Anesthesiology 1985; 63: A460.

10 Motoyama EK, Glazener $\mathrm{CH}$. Hypoxemia after general anesthesia in children. Anesth Analg 1986; 65: 267-72.

11 Soliman IE, Patel RI, Ehrenpreis MB, Hannallah $R S$. Recovery scores do not correlate with postoperative hypoxemia in children. Anesth Analg 1987; 67: 53-6.

12 Desoto H, Patel RI, Soliman IE, Hannallah RS. Changes in oxygen saturation following general anesthesia in children with upper respiratory infection signs and symptoms undergoing otolaryngological procedures. Anesthesiology 1988; 68: 276-9.

13 Vijayakumar $H R$, Metriyakool $K$, Jewell MR. Effect of 100 per cent oxygen and a mixture of oxygen and air on oxygen saturation in the immediate postoperative period in children. Ancsth Analg 1987; 66: 181-4.

14 Patel R, Norden J, Hannallah RS. Oxygen administration prevents hypoxemia during post-anesthetic transport in children. Anesthesiology 1988; 69: 616-8. 